\title{
Antigenic Relationships of the Mycobacterium fortuitum- Mycobacterium chelonae Complex
}

\author{
A. Y. TSANG, ${ }^{1}$ V. L. BARR, ${ }^{1}$ J. K. MCCLATCHY,${ }^{1 *}$ M. GOLDBERG,${ }^{1}$ I. DRUPA,${ }^{1}$ AND P. J. BRENNAN ${ }^{2}$ \\ National Jewish Hospital and Research Center/National Asthma Center, Denver, Colorado $80206^{1}$ and Department of \\ Microbiology, Colorado State University, Fort Collins, Colorado $80523^{2}$
}

\begin{abstract}
We used a combination of chemical analysis, seroagglutination, and an enzyme-linked immunosorbant assay to examine the glycolipids of the rapidly growing mycobacteria in order to define the basis of the antigenicity of these organisms. This dual chemical and serological approach established that the typing antigens of Mycobacterium chelonae subsp. chelonae belong to the polar C-mycoside glycopeptidolipid class, the major component of which contains a trisaccharide composed of 3,4-di- $O$-methylrhamnose, rhamnose, and 6-deoxytalose. The glycolipid patterns of $M$. chelonae subsp. abscessus and $M$. chelonae subsp. chelonae were identical. The same approach showed that there is no relationship between Mycobacterium fortuitum biovar fortuitum and Mycobacterium fortuitum biovar peregrinum. The specific lipids of $M$. fortuitum biovar peregrinum belong to the alkali-stable C-mycoside glycopeptidolipid class and are different from those of $M$. chelonae subsp. chelonae. $M$. fortuitum biovar fortuitum isolates produced three patterns of alkali-labile lipids with features of lipooligosaccharide antigens. Moreover, strains and antisera of $M$. fortuitum biovar fortuitum and $M$. fortuitum biovar peregrinum used in combination produced no cross-reactions. Thus, chemical analysis of the type-specific antigens is a powerful adjunct to serology for studying the antigenic relationships among rapidly growing mycobacteria, and our results support the reinstitution of "Mycobacterium peregrinum" as a species distinct from $M$. fortuitum.
\end{abstract}

Chemical analysis and serology (either agglutination or an enzyme-linked immunosorbent assay [ELISA]) of the specific lipid antigens of many slowly growing nontuberculous mycobacteria have proved to be powerful tools for examining the fundamental differences among species of Mycobacterium. This dual approach has been used with members of the Mycobacterium avium-Mycobacterium intracellulareMycobacterium scrofulaceum (MAIS) complex $(5,6,8)$, Mycobacterium simiae serovars I and II (unpublished data), Mycobacterium kansasii, Mycobacterium szulgai, and other species (P. J. Brennan and S. W. Hunter, Fed. Proc. 41:1173, 1982; S. W. Hunter, R. C. Murphy, K. Clay, M. B. Goren, and P. J. Brennan, J. Biol. Chem., in press). Accordingly, the characteristic antigens of nontuberculous mycobacteria have been found to belong to the following two classes: the C-mycoside glycopeptidolipids (6) and the trehalose-containing lipooligosaccharides (Brennan and Hunter, Fed. Proc. 41:1173, 1982; Hunter et al., in press). These antigens can be readily differentiated by thin-layer chromatography (TLC) after treatment of lipid extracts with alkali; the lipooligosaccharides are alkali labile and destroyed, whereas the glycopeptidolipids retain their basic structure and lipophilicity due to amide-linked acyl residues and simply lose acetyl substituents in the process $(7,9)$.

The realization that rapidly growing nontuberculous mycobacteria are opportunistic invaders of postoperative wounds and pulmonary lesions $(3,11,23)$ has led to renewed interest in the use of the inherent antigenicity of these organisms in identification and in the charting of epidemiological trends. Mycobacterium chelonae corrig. has been clearly differentiated from Mycobacterium fortuitum (13), and a number of parameters suggest that $M$. chelonae is the legitimate species name of mycobacteria that have been called, among other names, "Mycobacterium abscessus" and "Mycobacterium borstelense" (19). However, instead

\footnotetext{
* Corresponding author.
}

of one simple taxon, some experts have argued for the designation of two subspecies, $M$. chelonae subsp. chelonae and $M$. chelonae subsp. abscessus (14). Likewise, $M$. fortuitum has been differentiated into two biovars, $M$. fortuitum biovar peregrinum and $M$. fortuitum biovar fortuitum (15). In the present study we supplemented serology with the fundamental chemistry of the specific lipid antigens to understand better the basis of the antigenicity and surface structures of these molecules. In essence, the opportunistic members of Runyon group IV (17) were examined in light of new information on the immunochemistry of the mycobacteria.

\section{MATERIALS AND METHODS}

Mycobacteria. The standard strains used were obtained from the serotyping culture collection and from the Trudeau Mycobacterial Culture Collection, both of which are housed at the National Jewish Hospital and Research Center/National Asthma Center under the auspices of National Institutes of Health, the United States-Japan Co-operative Medical Sciences (Tuberculosis) Program. A total of 33 strains were obtained from patient specimens supplied by R. J. Wallace, Department of Microbiology, University of Texas Health Center, Tyler, and H. M. Sommers, Department of Pathology, Northwestern Memorial Hospital, Chicago, Ill. These included 9 strains from sputa, 12 strains from wounds, 2 strains from bone abscesses, 3 strains from breast abscesses, 2 strains from corneal ulcers, 1 strain from abdominal wall tissue, 1 strain from lung tissue, 1 strain from pleural fluid, and 2 strains from unknown sources. All of the strains were routinely grown in $5 \mathrm{ml}$ of $7 \mathrm{H} 11$ broth (9) and incubated for 5 days at $37^{\circ} \mathrm{C}$. Samples $(100 \mu \mathrm{l})$ were spread onto five $7 \mathrm{H} 11$ plates which were incubated at $37^{\circ} \mathrm{C}$ for 1 week. The growth from three plates was harvested into $10 \mathrm{ml}$ of phenolphosphate-buffered saline (PPBS) by scraping the plates with a bent capillary pipette and transferring the resulting suspension into a sterile screw-capped tube $(20$ by $125 \mathrm{~mm})$. The 
suspension was allowed to stand for approximately 3 weeks at room temperature before it was used in the seroagglutination procedure. The growth on the remaining two plates was harvested in sterile physiological saline and used as a source of lipid for TLC analysis and ELISA. Larger quantities of $M$. chelonae were grown in a Micro-Ferm fermentor (model MF-205; New Brunswick Scientific Co.) in Sauton medium (pH 6.8) modified by adding casein hydrolysate (22). The bacteria were harvested by siphoning and then autoclaved and lyophilized.

TLC for strain identification. The procedure developed previously for extracting lipids from the MAIS complex (9) was used without alteration for the rapidly growing mycobacteria. The lipids were dried and dissolved in $\mathrm{CHCl}_{3}$ $\mathrm{CH}_{3} \mathrm{OH}$ (2:1), and a portion was applied directly to TLC plates, which were developed in $\mathrm{CHCl}_{3}-\mathrm{CH}_{3} \mathrm{OH}-\mathrm{H}_{2} \mathrm{O}$ (60:12:1). All plates were sprayed with orcinol- $\mathrm{H}_{2} \mathrm{SO}_{4}$ and photographed (9). Where indicated, an alkali treatment was applied as described previously (9).

ELISA. The ELISA procedure which we used is a modification of a procedure described recently (12). Intact or alkali-stable lipids of $M$. chelonae subsp. chelonae, $M$. chelonae subsp. abscessus, and $M$. fortuitum biovar peregrinum were prepared as described above for TLC, and were suspended in ethanol with sonication. Samples $(50 \mu \mathrm{l})$ were added to each well of a 96-well polystyrene microtiter plate, allowed to dry overnight, and washed in a phosphatebuffered saline- $0.1 \%$ Tween 80 solution (PBS-Tween) for 10 min. Rabbit antiserum $(50 \mu \mathrm{l})$ was added, and after a 30 -min incubation at room temperature, the serum was aspirated and the wells were washed four times with PBS-Tween. Finally, $50 \mu \mathrm{l}$ of 1:1,000-diluted goat anti-rabbit immunoglobulin $G$ peroxidase-linked conjugate (Sigma Chemical Co.) in PBS-Tween was added to each well, and the preparations were incubated for $45 \mathrm{~min}$. After additional washes, 50 $\mu \mathrm{l}$ of $\mathrm{O}$-phenylenediamine- $\mathrm{H}_{2} \mathrm{O}_{2}$ substrate in citrate phosphate buffer (12) was added, and the plates were incubated in the dark for $30 \mathrm{~min}$. The reaction was stopped by adding 2.5 $\mathrm{N} \mathrm{H}_{2} \mathrm{SO}_{4}$, and absorption was read at $490 \mathrm{~nm}$ with a MicroELISA Reader (Dynatech Laboratories, Inc.).

Seroagglutination and absorption. The procedure used was modified from the method of Schaefer (18). A 3-week-old suspension of mycobacteria in PPBS was adjusted to an optical density at $525 \mathrm{~nm}$ of 0.3 with a Coleman Junior spectrophotometer. A $500-\mu \mathrm{l}$ amount of this suspension and $500 \mu \mathrm{l}$ of rabbit antisera prepared as described previously (18) against $M$. fortuitum biovar fortuitum strains Smith-6196 and Teichmiller, $M$. fortuitum biovar peregrinum strains New Mexico-680 and $12660, M$. chelonae subsp. chelonae strains TMC 1544 and Ryder, and $M$. chelonae subsp. abscessus strain TMC 1543 were placed in tubes ( 12 by 75 $\mathrm{mm})$. A control tube containing $500 \mu \mathrm{l}$ of PPBS was also used with the organism suspensions. Tubes were shaken and incubated at $37^{\circ} \mathrm{C}$. Using indirect light, we viewed agglutination after 4 and $24 \mathrm{~h}$. The reactions were recorded as $4+$ (complete agglutination) to 0 (no reaction). An identification was assigned when a $4+$ reaction occurred with one pair of antisera and no reaction was recorded with the other antisera. (The working titers of the rabbit antisera were determined to be the highest dilutions of the sera that gave complete agglutination of a homologous strain.)

Sera were absorbed with nonhomologous strains as follows. A heavy suspension of the test organism was prepared by centrifugation for $10 \mathrm{~min}$ at 1,000 relative centrifugal force and suspended in an equal volume of PPBS. A sample $(500 \mu \mathrm{I})$ was mixed with an equal volume of 1:10-diluted antiserum and incubated overnight at $4^{\circ} \mathrm{C}$. The absorbed antiserum was removed after centrifugation at 1,000 relative centrifugal force for $15 \mathrm{~min}$, serially diluted, and titrated against homologous and heterologous strains. Those antisera that reduced the nonhomologous serum titer fourfold or less were considered to have low antibody-absorbing capacities and to be antigenically different from the corresponding type. The strains with high antibody-absorbing capacities were considered antigenically similar to the corresponding type.

Isolation of the glycopeptidolipid antigen of $M$. chelonae. Lyophilized cells $(31 \mathrm{~g})$ were extracted with 1.22 liter of $\mathrm{CHCl}_{3}-\mathrm{CH}_{3} \mathrm{OH}(2: 1)$ with stirring at room temperature for 18 $\mathrm{h}$; this was followed by further extraction with 0.5 volume of extractant at $50^{\circ} \mathrm{C}$. The dried lipid was dissolved in $300 \mathrm{ml}$ of $\mathrm{CHCl}_{3}-\mathrm{CH}_{3} \mathrm{OH}-\mathrm{H}_{2} \mathrm{O}(8: 4: 3)$ and centrifuged, and the separated phases were washed with separate upper and lower phases. The combined lower phases were dried, and dissolved in $30 \mathrm{ml}$ of $\mathrm{CHCl}_{3}-\mathrm{CH}_{3} \mathrm{OH}(2: 1)$, and this was followed by the addition of an equal volume of $0.2 \mathrm{M} \mathrm{NaOH}$ in $\mathrm{CH}_{3} \mathrm{OH}$ (9). The mixture was maintained at $37^{\circ} \mathrm{C}$ for 20 min, neutralized with glacial acetic acid $(750 \mu \mathrm{l})$, dried on a rotary evaporator, and partitioned between $50 \mathrm{ml}$ of $\mathrm{CH}_{3} \mathrm{Cl}_{3^{-}}$ $\mathrm{CH}_{3} \mathrm{OH}(2: 1)$ and $10 \mathrm{ml}$ of water.

The dried organic phase containing the washed alkalistable glycopeptidolipids was applied to a column of silicic acid-Celite $(2: 1)$ which was irrigated with $\mathrm{CHCl}_{3}(500 \mathrm{ml})$, followed by $300 \mathrm{ml}$ each of $2,3.5$, and $5 \% \mathrm{CH}_{3} \mathrm{OH}$ in $\mathrm{CHCl}_{3}$. The $\mathrm{CH}_{3} \mathrm{OH}$-containing eluates were collected in fractions of about $50 \mathrm{ml}$ each, dried, washed, and examined by TLC.

Isolation of $\mathbf{r}-\mathrm{Ose}_{\mathbf{n}}$ from the polar glycopeptidolipid of $\boldsymbol{M}$. chelonae. To isolate reduced oligosaccharide ( $r-\mathrm{Ose}_{\mathrm{n}}$ ), partially purified polar glycopeptidolipid from a silicic acid column was subjected to alkaline borohydride reductive cleavage ( $\beta$-elimination) as follows. To $148 \mathrm{mg}$ of the lipid were added $5 \mathrm{ml}$ of ethanol and $1 \mathrm{ml}$ of water (8). The suspension was heated at $60^{\circ} \mathrm{C}$ and briefly sonicated to aid dissolution; $1 \mathrm{~N} \mathrm{NaOH} \mathrm{(4} \mathrm{ml)} \mathrm{was} \mathrm{added,} \mathrm{followed} \mathrm{by} 454 \mathrm{mg}$ of $\mathrm{NaBH}_{4}$ and a small crystal of ${ }^{3} \mathrm{H}$-labeled $\mathrm{NaBH}_{4}$. The mixture, which was in a tightly sealed tube, was allowed to react at $60^{\circ} \mathrm{C}$ for $21 \mathrm{~h}$. Then it was neutralized with $2 \mathrm{M}$ $\mathrm{CH}_{3} \mathrm{COOH}$, dried on the rotary evaporator, and partitioned between equal volumes of $\mathrm{CHCl}_{3}-\mathrm{CH}_{3} \mathrm{OH}$ (2:1) and water, The dried aqueous phase was applied to a column (102 by 2 $\mathrm{cm}$ ) of Sephadex G-15, which was eluted with water. Fractions $(2 \mathrm{ml})$ were analyzed for carbohydrate $(8)$ and counted for radioactivity. Incidental to this operation, the organic phase from the $\beta$-elimination reaction was chromatographed on thin-layer plates in $\mathrm{CHCl}_{3}-\mathrm{CH}_{3} \mathrm{OH}-2 \% \mathrm{CH}_{3} \mathrm{COONa}$ (45:3:0.3) and compared with a similar product derived from the glycopeptidolipid antigen of $M$. intracellulare serovar 9 $(6,8)$.

Other analytical procedures. Most of the chemical procedures used have been described previously $(6,8)$. Cellulose TLC plates $(0.1 \mathrm{~mm})$ were obtained from E. Merck, and silica gel TLC plates (Redi-Plates) were obtained from Fisher Scientific Co. Reducing sugars were located on cellulose thin-layer plates with aniline-oxalate (6). Paper chromatography was conducted as described previously (8) by using an $\mathrm{AgNO}_{3}-\mathrm{NaOH}$ dip reagent to locate the oligosaccharides. The oligosaccharides were hydrolyzed with $2 \mathrm{M}$ $\mathrm{CF}_{3} \mathrm{COOH}$ in steam for $3 \mathrm{~h}$. Alditol acetates were prepared as described previously (8). Gas-liquid chromatography was conducted with a Hewlett-Packard model 5800A gas chromatograph attached to a Hewlett-Packard model 3380A intergrator. Further details are provided in the legend to Fig. 4. 
TABLE 1. Comparison of strains identified as $M$. chelonae by traditional biochemical means, seroagglutination, and TLC

\begin{tabular}{|c|c|c|c|c|c|c|c|}
\hline \multirow[b]{2}{*}{ Strain $^{a}$} & \multirow[b]{2}{*}{$\begin{array}{l}\text { Identification based } \\
\text { on biochemical } \\
\text { reactions }\end{array}$} & \multicolumn{4}{|c|}{ Antiserum reactions } & \multirow[b]{2}{*}{$\begin{array}{l}\text { Identification based on } \\
\text { serology }\end{array}$} & \multirow[b]{2}{*}{$\begin{array}{c}\text { Identification based on TLC } \\
\text { of lipid antigens }\end{array}$} \\
\hline & & $\begin{array}{l}\text { M. fortui- } \\
\text { tum biovar } \\
\text { fortuitum }\end{array}$ & $\begin{array}{l}\text { M. fortui- } \\
\text { tum biovar } \\
\text { peregrinum }\end{array}$ & $\begin{array}{l}\text { M. chelo- } \\
\text { nae subsp. } \\
\text { abscessus }\end{array}$ & $\begin{array}{l}M . \text { chelo- } \\
\text { nae subsp. } \\
\text { chelonae }\end{array}$ & & \\
\hline Sullivan & $\begin{array}{l}\text { M. chelonae } \\
\text { subsp. chelonae }\end{array}$ & - & ++ & $+t+$ & ++++ & $\begin{array}{l}\text { M. chelonae subsp. che- } \\
\text { lonae, } M \text {. chelonae } \\
\text { subsp. abscessus }\end{array}$ & $\begin{array}{l}\text { M. chelonae subsp. che- } \\
\text { lonae, } M \text {. chelonae } \\
\text { subsp. abscessus }\end{array}$ \\
\hline TMC 1542 & $\begin{array}{l}\text { M. chelonae } \\
\text { subsp. chelonae }\end{array}$ & - & + & ++++ & ++++ & $\begin{array}{l}\text { M. chelonae subsp. che- } \\
\text { lonae, } M \text {. chelonae } \\
\text { subsp. abscessus }\end{array}$ & $\begin{array}{l}\text { M. chelonae subsp. che- } \\
\text { lonae, } M \text {. chelonae } \\
\text { subsp. abscessus }\end{array}$ \\
\hline TMC 1544 & $\begin{array}{l}\text { M. chelonae } \\
\text { subsp. chelonae }\end{array}$ & - & - & ++++ & ++++ & $\begin{array}{l}\text { M. chelonae subsp. che- } \\
\text { lonae, } M \text {. chelonae } \\
\text { subsp. abscessus }\end{array}$ & $\begin{array}{l}\text { M. chelonae subsp. che- } \\
\text { lonae, } M \text {. chelonae } \\
\text { subsp. abscessus }\end{array}$ \\
\hline 3-29 & M. chelonae & - & - & ++++ & ++++ & $\begin{array}{l}\text { M. chelonae subsp. che- } \\
\text { lonae, } M \text {. chelonae } \\
\text { subsp. abscessus }\end{array}$ & $\begin{array}{l}\text { M. chelonae subsp. che- } \\
\text { lonae, } M \text {. chelonae } \\
\text { subsp. abscessus }\end{array}$ \\
\hline $4-28$ & M. fortuitum & - & ++++ & ++++ & ++++ & $\begin{array}{l}\text { M. fortuitum biovar pere- } \\
\text { grinum, } M \text {. chelonae } \\
\text { subsp. chelonae, } M \text {. } \\
\text { chelonae subsp. absces- } \\
\text { sus }\end{array}$ & $\begin{array}{l}\text { M. fortuitum biovar pere- } \\
\text { grinum }\end{array}$ \\
\hline $6-11$ & M. chelonae & - & ++ & ++++ & ++++ & $\begin{array}{l}\text { M. chelonae subsp. che- } \\
\text { lonae, } M \text {. chelonae } \\
\text { subsp. abscessus }\end{array}$ & $\begin{array}{l}\text { M. chelonae subsp. che- } \\
\text { lonae, } M \text {. chelonae } \\
\text { subsp. abscessus }\end{array}$ \\
\hline $1-8$ & $M$. chelonae & - & ++ & +++ & ++++ & $\begin{array}{l}\text { M. chelonae subsp. che- } \\
\text { lonae, } M \text {. chelonae } \\
\text { subsp. abscessus }\end{array}$ & $\begin{array}{l}\text { M. chelonae subsp. che- } \\
\text { lonae, } M \text {. chelonae } \\
\text { subsp. abscessus }\end{array}$ \\
\hline $3-7$ & M. chelonae & - & ++ & ++++ & ++++ & $\begin{array}{l}M \text {. chelonae subsp. che- } \\
\text { lonae, } M \text {. chelonae } \\
\text { subsp. abscessus }\end{array}$ & $\begin{array}{l}\text { M. chelonae subsp. che- } \\
\text { lonae, } M \text {. chelonae } \\
\text { subsp. abscessus }\end{array}$ \\
\hline $3-16$ & M. chelonae & - & + & ++++ & ++++ & $\begin{array}{l}\text { M. chelonae subsp. che- } \\
\text { lonae, } M \text {. chelonae } \\
\text { subsp. abscessus }\end{array}$ & $\begin{array}{l}\text { M. chelonae subsp. che- } \\
\text { lonae, } M \text {. chelonae } \\
\text { subsp. abscessus }\end{array}$ \\
\hline $3-22$ & M. chelonae & - & +++ & ++++ & ++++ & $\begin{array}{l}M \text {. chelonae subsp. che- } \\
\text { lonae, } M \text {. chelonae } \\
\text { subsp. abscessus }\end{array}$ & $\begin{array}{l}\text { M. chelonae subsp. che- } \\
\text { lonae, } M \text {. chelonae } \\
\text { subsp. abscessus }\end{array}$ \\
\hline $6-40$ & M. chelonae & - & +++ & ++++ & $+++t$ & $\begin{array}{l}\text { M. chelonae subsp. che- } \\
\text { lonae, } M \text {. chelonae } \\
\text { subsp. abscessus }\end{array}$ & $\begin{array}{l}\text { M. chelonae subsp. che- } \\
\text { lonae, } M \text {. chelonae } \\
\text { subsp. abscessus }\end{array}$ \\
\hline $8-1$ & M. fortuitum & - & + & ++++ & +++ & $\begin{array}{l}\text { M. chelonae subsp. che- } \\
\text { lonae, } M \text {. chelonae } \\
\text { subsp. abscessus }\end{array}$ & $\begin{array}{l}\text { M. chelonae subsp. che- } \\
\text { lonae, } M \text {. chelonae } \\
\text { subsp. abscessus }\end{array}$ \\
\hline $8-12$ & M. fortuitum & - & ++ & ++++ & +++ & $\begin{array}{l}\text { M. chelonae subsp. che- } \\
\text { lonae, } M \text {. chelonae } \\
\text { subsp, abscessus }\end{array}$ & $\begin{array}{l}\text { M. chelonae subsp. che- } \\
\text { lonae, } M \text {. chelonae } \\
\text { subsp. abscessus }\end{array}$ \\
\hline $8-13$ & $M$. fortuitum & - & ++ & ++++ & +++ & $\begin{array}{l}\text { M. chelonae subsp. che- } \\
\text { lonae, } M \text {. chelonae } \\
\text { subsp. abscessus }\end{array}$ & $\begin{array}{l}\text { M. chelonae subsp. che- } \\
\text { lonae, } M \text {. chelonae } \\
\text { subsp. abscessus }\end{array}$ \\
\hline $8-21$ & M. fortuitum & - & + & ++++ & +++ & $\begin{array}{l}\text { M. chelonae subsp. che- } \\
\text { lonae, } M \text {. chelonae } \\
\text { subsp. abscessus }\end{array}$ & $\begin{array}{l}\text { M. chelonae subsp. che- } \\
\text { lonae, } M \text {. chelonae } \\
\text { subsp. abscessus }\end{array}$ \\
\hline TMC 1543 & $\begin{array}{l}\text { M. chelonae } \\
\text { subsp. abscessus }\end{array}$ & - & +++ & ++++ & +++ & $\begin{array}{l}\text { M. chelonae subsp. che- } \\
\text { lonae, } M \text {. chelonae } \\
\text { subsp. abscessus }\end{array}$ & $\begin{array}{l}\text { M. chelonae subsp. che- } \\
\text { lonae, M. chelonae } \\
\text { subsp. abscessus }\end{array}$ \\
\hline
\end{tabular}

${ }^{a}$ All isolates except strains Sullivan, TMC 1542, TMC 1544, and TMC 1543 were obtained from R. J. Wallace and H. M. Sommers.

\section{RESULTS}

Seroagglutination of $M$. chelonae subspecies. Table 1 shows the agglutination reactions of reference strains which had been classified as $M$. chelonae subsp. chelonae or $M$. chelonae subsp. abscessus, as well as clinical isolates, some of which were considered $M$. fortuitum based largely on biochemical reactions (19). There was no difference in the agglutination reactions of the $M$. chelonae subsp. chelonae strains and the one $M$. chelonae subsp. abscessus reference strain. With some of the clinical isolates (strains 8-1, 8-12, and 8-13), slightly weaker, although probably insignificant, reactions occurred with $M$. chelonae subsp. chelonae antisera. Strain 4-28 gave a distinctly positive reaction with the $M$. fortuitum biovar peregrinum antisera, but full corroboration of this identification had to await TLC analysis. $M$. chelonae subsp. chelonae and $M$. chelonae subsp. abscessus strains reacted to variable extents with $M$. fortuitum biovar peregrinum antiserum, but there were no responses to $M$. fortuitum biovar fortuitum sera.

TLC of the lipid antigens of $M$. chelonae subsp. abscessus. Figure 1A shows the results of chromatography of the total 
A

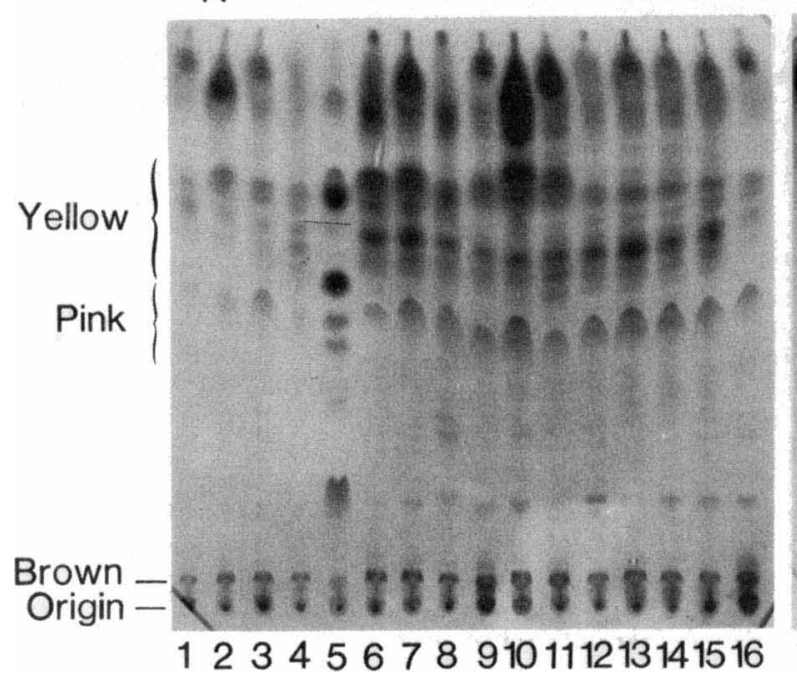

B

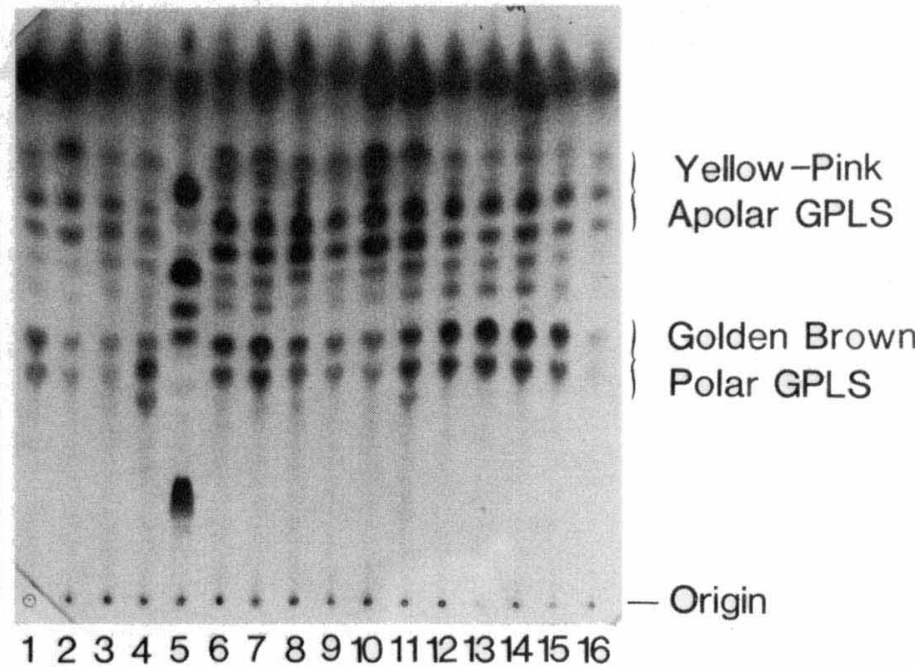

FIG. 1. (A) TLC of the intact lipids from reference strains and clinical isolates of $M$. chelonae subsp. chelonae and $M$. chelonae subsp. abscessus and one isolate of $M$. fortuitum biovar peregrinum (lane 5). The solvent used was $\mathrm{CHCl}_{3}-\mathrm{CH}_{3} \mathrm{OH}-\mathrm{H}_{2} \mathrm{O}(60: 12: 1)$, and the spray used was orcinol- $\mathrm{H}_{2} \mathrm{SO}_{4}$. (B) TLC of the alkali-stable lipids under the same conditions. Lane 1, Strain Sullivan; lane 2, strain TMC 1542; lane 3, strain TMC 1544; lane 4, strain 3-29; lane 5, strain 4-28; lane 6, strain 6-11; lane 7, strain 1-8; lane 8, strain 3-7; lane 9, strain 3-16; lane 10, strain 3-22; lane 11, strain 6-40; lane 12, strain 8-1; lane 13, strain 8-12; lane 14, strain 8-13; lane 15, strain 8-21; lane 16, strain TMC 1543. GPLS, Glycopeptidolipids.

untreated lipids from the strains shown in Table 1. With one exception (strain 4-28 [Fig. 1A, lane 5]), the profiles of the lipids of all isolates were identical, albeit not particularly striking. Nevertheless, spots with a yellow to golden hue were evident, and, as indicated elsewhere $(7,9)$, such a response to the orcinol spray is highly indicative of the presence of glycopeptidolipids. These molecules are resistant to alkali, whereas the majority of the nonspecific lipids shown in Fig. 1A are susceptible. The products of mild treatment with $\mathrm{NaOH}$ were predominantly yellow-tinged spots and were fewer in number, presumably due to the absence of multiacetylated varieties (Fig. 1B). Again, all isolates of $M$. chelonae subsp. chelonae and $M$. chelonae subsp. abscessus were identical in this respect, and the isolates for which biochemical parameters suggested identification as $M$. fortuitum but serology suggested otherwise were obviously $M$. chelonae. The one exception (strain 4-28 [Fig. 1B, lane 5]), for which serology suggested identification as $M$. fortuitum biovar peregrinum, produced a spectrum of glycopeptidolipids that was characteristic of $M$. fortuitum biovar peregrinum (see below).

Structure of the polar glycopeptidolipid from $M$. chelonae. The yield of washed lipids from a typical batch of $31 \mathrm{~g}$ of $M$. chelonae cells grown in modified Sauton medium was $3.23 \mathrm{~g}$. Such preparations were treated with $0.2 \mathrm{M} \mathrm{NaOH}$ in order to destroy the unwanted glycerides and simplify the pattern of glycopeptidolipids, thereby facilitating isolation of the species-specific polar glycopeptidolipid (2). Irrigation of silicic acid to which the alkali-stable lipids had been applied with $\mathrm{CHCl}_{3}$, followed by irrigation with $2 \% \mathrm{CH}_{3} \mathrm{OH}$ in $\mathrm{CHCl}_{3}$, removed the unwanted fatty acids. Subsequent irrigation with $3.5 \% \mathrm{CH}_{3} \mathrm{OH}$ in $\mathrm{CHCl}_{3}$ removed the apolar glycopeptidolipids, whereas 3.5 and $5 \% \mathrm{CH}_{3} \mathrm{OH}$ elutrients provided the polar (presumed antigenic) glycopeptidolipids. About $340 \mathrm{mg}$ of total glycopeptidolipids was recovered in the process, of which about $140 \mathrm{mg}$ was of the polar variety. This latter mixture was subjected to reductive $\beta$-elimination in the presence of ${ }^{3} \mathrm{H}$-labeled $\mathrm{NaBH}_{4}(8)$, and the water-soluble products were applied to a Sephadex G-25 column (Fig. 2). The mixed carbohydrate-containing fractions yielded $17 \mathrm{mg}$ of ${ }^{3} \mathrm{H}$-labeled $r-$ Ose $_{n}$ that was largely free of inorganic reaction products. The lipid products of the $\beta$-elimination reaction were subjected to TLC in $\mathrm{CHCl}_{3}-\mathrm{CH}_{3} \mathrm{OH}-2 \%$ $\mathrm{CH}_{3} \mathrm{COONa}(45: 30: 0.3)(8)$. The major product had a mobil-

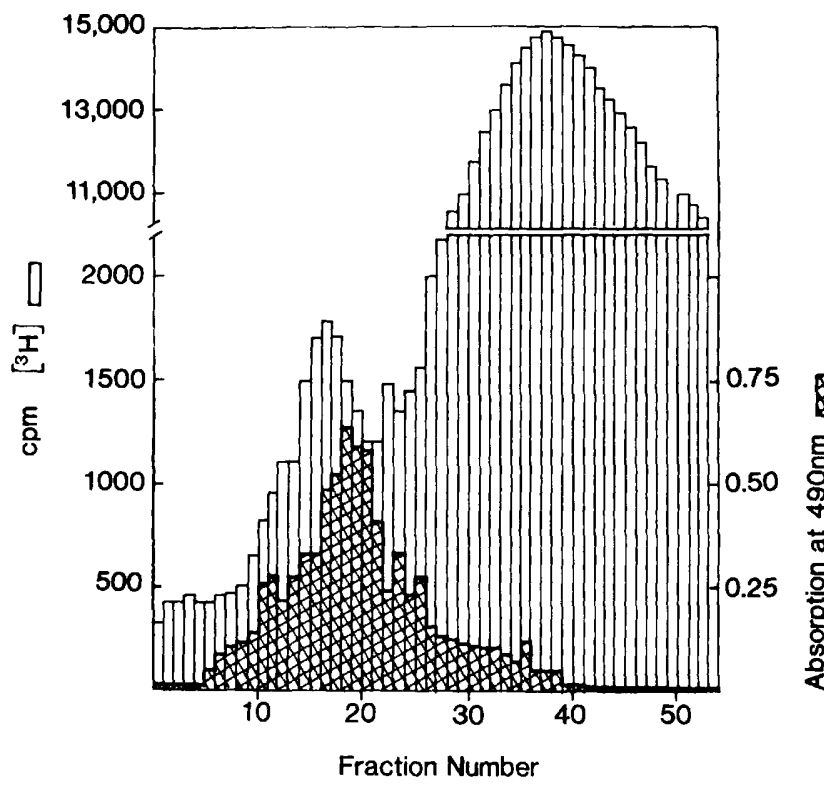

FIG. 2. Gel filtration on a Sephadex G-15 column (110 by $1.5 \mathrm{~cm}$ ) of the water-soluble products from reductive $\left(\mathrm{NaB}^{3} \mathrm{H}_{4}\right)$ alkaline cleavage of the polar glycopeptidolipids from $M$. chelonae. About 20 $\mathrm{mg}\left(2.35 \times 10^{6} \mathrm{cpm}\right)$ of rhamnose equivalents was applied, and about $17 \mathrm{mg}\left(2 \times 10^{6} \mathrm{cpm}\right)$ was recovered in the mixed carbohydrate peak. 
ity which was identical to that of similarly derived products from MAIS complex serovars $(6,8)$. This product was isolated by preparative TLC and hydrolyzed, and gas-liquid chromatography of the sugar (as its alditol acetate) showed that it was 3,4-di- $O$-methylrhamnose (data not shown). Thus, the fatty acylpeptidyl-monoglycosyl backbone of the glycopeptidolipid from $M$. chelonae seems to be identical to that from serovars of the MAIS complex (8).

Paper chromatography of ${ }^{3} \mathrm{H}$-labeled $\mathrm{r}$-Ose $\mathrm{n}_{\mathrm{n}}$ from the $M$. chelonae subsp. chelonae glycopeptidolipid showed chromatographic mobility in the region of known hexose-containing disaccharides (Fig. 3). The ${ }^{3} \mathrm{H}$-labeled $\mathrm{r}-\mathrm{Ose}_{\mathrm{n}}$ was hydrolyzed, chromatographed on cellulose thin layers, and stained with aniline-oxalate for reducing sugars. Only two such sugars were located, and these corresponded to rhamnose and 3,4-di- $O$-methylrhamnose. However, gas-liquid chromatography of the alditol acetates from ${ }^{3} \mathrm{H}$-labeled $\mathrm{r}-\mathrm{Ose}_{3}$ showed that the following three components were present (Fig. 4): the acetates of 6-deoxytalitol, rhamnitol, and 3,4-di$O$-methylrhamnitol. Obviously, as in the case of other r-Ose (5), the nonreducing 6-deoxytalitol occurred in the ${ }^{3} \mathrm{H}$ labeled $\mathrm{r}-\mathrm{Ose}_{\mathrm{n}}$ from $M$. chelonae. Thus, the $\mathrm{r}-\mathrm{Ose}_{\mathrm{n}}$ is a 6deoxyhexose-containing trisaccharide $\left(r-\mathrm{Ose}_{3}\right)$ which has chromatographic properties like those of hexose-containing disaccharides. In the glycopeptidolipid antigens from MAIS complex serovars, rhamnose always occupies the second position and is linked to 6-deoxytalitol through an $\alpha-1 \rightarrow 2$ linkage, whereas $O$-methyl-6-deoxyhexoses occupy ultimate or penultimate positions (5). Hence, through a process of direct analysis, comparison with the products from the MAIS complex, and deduction, we propose the following incomplete and tentative structure for the $\mathrm{r}-\mathrm{Ose}_{3}$ from $M$. chelonae: 3,4-di-O-methylrhamnose-(1 $\rightarrow$ ?)-rhamnose- $(\alpha-$ $1 \rightarrow 2$ )-6-deoxytalitol.

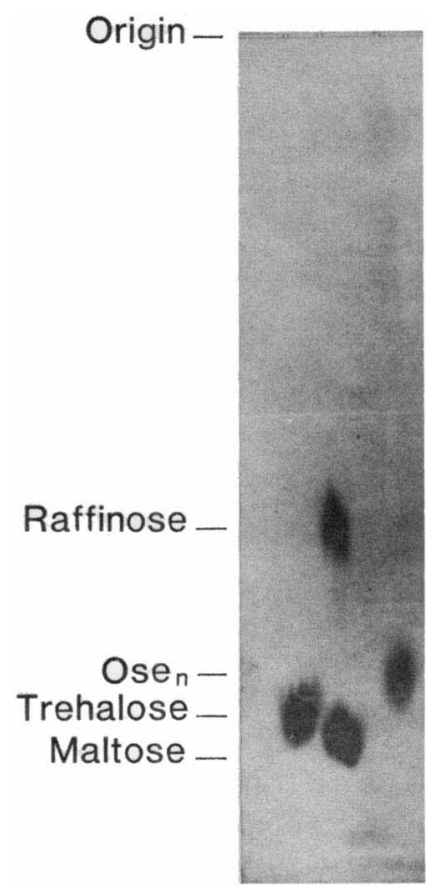

FIG. 3. Descending paper chromatography on Whatman no. 1 paper of ${ }^{3} \mathrm{H}$-labeled $\mathrm{r}$-Ose $\mathrm{n}_{\mathrm{n}}$ from $M$. chelonae subsp. chelonae along with raffinose, maltose, and trehalose. Oligosaccharides were located with $\mathrm{AgNO}_{3}-\mathrm{NaOH}$. The solvent used was 1-butanol-pyridinewater $(6: 4: 3)$.

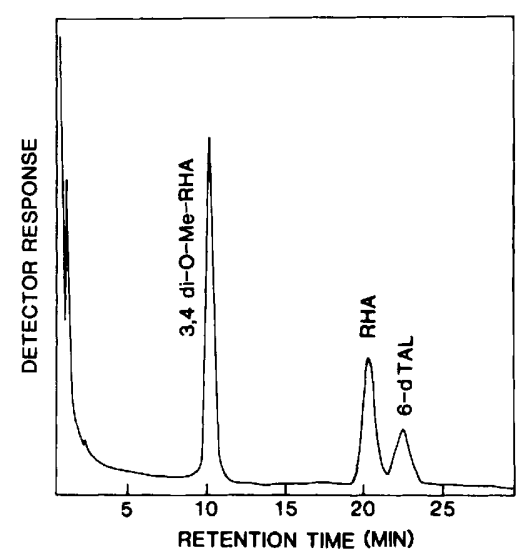

FIG. 4. Gas-liquid chromatography of the alditol acetates derived from pure ${ }^{3} \mathrm{H}$-labeled $\mathrm{r}$-Ose $\mathrm{n}_{\mathrm{n}}$ of $M$. chelonae subsp. chelonae. About $35 \mu \mathrm{g}$ of the r-Ose $\mathrm{n}_{\mathrm{n}}$ was hydrolyzed with $2 \mathrm{M} \mathrm{CF}_{3} \mathrm{COOH}$ in a steam bath for $3 \mathrm{~h}$, and the products were reduced and acetylated. The following operating conditions were used: $3 \%$ SP-2340 on 100120 Supelcoport; $175^{\circ} \mathrm{C}$; $60 \mathrm{ml}$ of $\mathrm{N}_{2}$ per min. Me, Methyl; RHA, rhamnose; 6-dTAL, 6-deoxytalose.

ELISA and the glycopeptidolipid antigens of rapidly growing mycobacteria. The application of the ELISA to glycopeptidolipids per se, including those of the MAIS complex, $M$. simiae serovars I and II, Mycobacterium malmoense, $M$. chelonae subsp. chelonae, $M$. chelonae subsp. abscessus, and $M$. fortuitum biovar peregrinum, will be reported separately (C. V. Knisely, V. L. Barr, A. Y. Tsang, J. K. McClatchy, and P. J. Brennan, manuscript in preparation). Briefly, whole lipid extracts from $M$. chelonae subsp. chelonae, $M$. chelonae subsp. abscessus, and $M$. fortuitum biovar peregrinum strains reacted readily in the ELISA with serum to the homologous strain. Alkali treatment of the extracts did not diminish the activity, thereby verifying that the alkali-stable glycopeptidolipids were the active substances. The reactions of $M$. chelonae subsp. chelonae lipid with anti- $M$. chelonae subsp. abscessus serum were only about one-third the reactions of the homologous pair. Likewise, when the reverse reaction was conducted, there was not full equivalence. However, less than full correspondence even among different strains belonging to the one MAIS complex serovar is common with the ELISA (D. L. Yanagihara, unpublished data).

Seroagglutination of $\boldsymbol{M}$. fortuitum biovars. Table 2 shows the agglutination reactions of reference strains and a selection of clinical isolates of $M$. fortuitum biovar fortuitum and $M$. fortuitum biovar peregrinum. Strains of $M$. fortuitum biovar fortuitum which produced unequivocal seroagglutination and TLC results did not cross-react with $M$. fortuitum biovar peregrinum, $M$. chelonae subsp. abscessus, and $M$. chelonae subsp. chelonae antisera. Thus, strain 5-34 proved to be $M$. fortuitum biovar fortuitum and not $M$. chelonae. On the other hand, strain 7-56 proved to be $M$. fortuitum biovar peregrinum. The same relationship was true for 18 other isolates supplied by R. J. Wallace and H. M. Sommers. Although $M$. chelonae subsp. chelonae and $M$. chelonae subsp. abscessus cross-reacted with $M$. fortuitum biovar peregrinum antisera, there was no cross-reaction with $M$. fortuitum biovar fortuitum antisera. Thus, our results support the hypothesis that there is a major antigenic difference between $M$. fortuitum biovar fortuitum and $M$. fortuitum biovar peregrinum and corroborate the results of Jenkins et al. (13). 
TABLE 2. Comparison of strains identified as $M$. fortuitum biovar fortuitum and $M$. fortuitum biovar peregrinum by traditional biochemical means, seroagglutination, and TLC

\begin{tabular}{|c|c|c|c|c|c|c|c|}
\hline \multirow[b]{2}{*}{ Strain } & \multirow[b]{2}{*}{$\begin{array}{l}\text { Identification based on } \\
\text { biochemical reactions }\end{array}$} & \multicolumn{4}{|c|}{ Antiserum reactions } & \multirow[b]{2}{*}{$\begin{array}{l}\text { Identification based } \\
\text { on serology }\end{array}$} & \multirow[b]{2}{*}{$\begin{array}{l}\text { Identification based } \\
\text { on TLC of lipid } \\
\text { antigens }\end{array}$} \\
\hline & & $\begin{array}{l}\text { M. fortuitum } \\
\text { biovar } \\
\text { fortuitum }\end{array}$ & $\begin{array}{l}\text { M. fortuitum } \\
\text { biovar } \\
\text { peregrinum }\end{array}$ & $\begin{array}{l}\text { M. chelonae } \\
\text { subsp. } \\
\text { abscessus }\end{array}$ & $\begin{array}{l}\text { M. chelonae } \\
\text { subsp. } \\
\text { chelonae }\end{array}$ & & \\
\hline $5-34$ & M. chelonae & ++++ & - & - & - & $\begin{array}{l}\text { M. fortuitum biovar } \\
\text { fortuitum }\end{array}$ & $\begin{array}{l}\text { M. fortuitum biovar } \\
\text { fortuitum }\end{array}$ \\
\hline $7-82$ & M. fortuitum & ++++ & - & - & - & $\begin{array}{l}\text { M. fortuitum biovar } \\
\text { fortuitum }\end{array}$ & $\begin{array}{l}\text { M. fortuitum biovar } \\
\text { fortuitum }\end{array}$ \\
\hline $5-8$ & M. fortuitum & ++++ & ++++ & +++ & ++++ & $\begin{array}{l}\text { Spontaneous } \\
\text { agglutination }\end{array}$ & $\begin{array}{l}\text { M. fortuitum biovar } \\
\text { fortuitum }\end{array}$ \\
\hline $10-32$ & $\begin{array}{l}\text { M. fortuitum biovar } \\
\text { fortuitum }\end{array}$ & - & - & - & - & Untypable & $\begin{array}{l}\text { M. fortuitum biovar } \\
\text { fortuitum }\end{array}$ \\
\hline $10-33$ & $\begin{array}{l}\text { M. fortuitum biovar } \\
\text { fortuitum }\end{array}$ & +++ & - & - & - & $\begin{array}{l}\text { M. fortuitum biovar } \\
\text { fortuitum }\end{array}$ & $\begin{array}{l}\text { M. fortuitum biovar } \\
\text { fortuitum }\end{array}$ \\
\hline $10-34$ & $\begin{array}{l}\text { M. fortuitum biovar } \\
\text { fortuitum }\end{array}$ & + & - & - & - & Untypable & $\begin{array}{l}\text { M. fortuitum biovar } \\
\text { fortuitum }\end{array}$ \\
\hline $10-36$ & $\begin{array}{l}\text { M. fortuitum biovar } \\
\text { fortuitum }\end{array}$ & - & - & - & - & Untypable & $\begin{array}{l}\text { M. fortuitum biovar } \\
\text { fortuitum }\end{array}$ \\
\hline $10-37$ & $\begin{array}{l}\text { M. fortuitum biovar } \\
\text { fortuitum }\end{array}$ & - & - & - & - & Untypable & $\begin{array}{l}\text { M. fortuitum biovar } \\
\text { fortuitum }\end{array}$ \\
\hline $10-38$ & $M$. fortuitum group $3^{a}$ & - & - & - & - & Untypable & $\begin{array}{l}\text { M. fortuitum biovar } \\
\text { fortuitum }\end{array}$ \\
\hline $10-35$ & $\begin{array}{l}\text { M. fortuitum biovar } \\
\text { peregrinum }\end{array}$ & - & +++ & ++++ & +++ & $\begin{array}{l}\text { M. fortuitum biovar } \\
\text { peregrinum }\end{array}$ & $\begin{array}{l}\text { M. fortuitum biovar } \\
\text { peregrinum }\end{array}$ \\
\hline $11-19$ & $\begin{array}{l}\text { M. fortuitum biovar } \\
\text { fortuitum }\end{array}$ & ++++ & - & - & - & $\begin{array}{l}\text { M. fortuitum biovar } \\
\text { fortuitum }\end{array}$ & $\begin{array}{l}\text { M. fortuitum biovar } \\
\text { fortuitum }\end{array}$ \\
\hline $11-20$ & $\begin{array}{l}\text { M. fortuitum biovar } \\
\text { fortuitum }\end{array}$ & ++++ & - & - & - & $\begin{array}{l}\text { M. fortuitum biovar } \\
\text { fortuitum }\end{array}$ & $\begin{array}{l}\text { M. fortuitum biovar } \\
\text { fortuitum }\end{array}$ \\
\hline $11-21$ & $\begin{array}{l}\text { M. fortuitum biovar } \\
\text { fortuitum }\end{array}$ & ++++ & - & - & - & $\begin{array}{l}\text { M. fortuitum biovar } \\
\text { fortuitum }\end{array}$ & $\begin{array}{l}\text { M. fortuitum biovar } \\
\text { fortuitum }\end{array}$ \\
\hline $11-22$ & $\begin{array}{l}\text { M. fortuitum biovar } \\
\text { fortuitum }\end{array}$ & ++++ & - & - & - & $\begin{array}{l}\text { M. fortuitum biovar } \\
\text { fortuitum }\end{array}$ & $\begin{array}{l}\text { M. fortuitum biovar } \\
\text { fortuitum }\end{array}$ \\
\hline $11-23$ & $\begin{array}{l}\text { M. fortuitum biovar } \\
\text { fortuitum }\end{array}$ & ++++ & - & - & - & $\begin{array}{l}\text { M. fortuitum biovar } \\
\text { fortuitum }\end{array}$ & $\begin{array}{l}\text { M. fortuitum biovar } \\
\text { fortuitum }\end{array}$ \\
\hline $11-24$ & $\begin{array}{l}\text { M. fortuitum biovar } \\
\text { fortuitum }\end{array}$ & +++ & - & - & - & $\begin{array}{l}\text { M. fortuitum biovar } \\
\text { fortuitum }\end{array}$ & $\begin{array}{l}\text { M. fortuitum biovar } \\
\text { fortuitum }\end{array}$ \\
\hline $11-25$ & M. fortuitum & ++++ & +++ & +++ & +++ & $\begin{array}{l}\text { Spontaneous } \\
\text { agglutination }\end{array}$ & $\begin{array}{l}\text { M. fortuitum biovar } \\
\text { fortuitum }\end{array}$ \\
\hline $11-26$ & $M$. fortuitum group $3^{a}$ & - & ++++ & ++ & ++ & $\begin{array}{l}\text { M. fortuitum biovar } \\
\text { peregrinum }\end{array}$ & $\begin{array}{l}\text { M. fortuitum biovar } \\
\text { peregrinum }\end{array}$ \\
\hline TMC 1529 & M. fortuitum & ++++ & - & - & - & $\begin{array}{l}\text { M. fortuitum biovar } \\
\text { fortuitum }\end{array}$ & $\begin{array}{l}\text { M. fortuitum biovar } \\
\text { fortuitum }\end{array}$ \\
\hline $\begin{array}{l}\text { Starr- } \\
\quad \text { Glidden }\end{array}$ & $\begin{array}{l}\text { M. fortuitum biovar } \\
\text { peregrinum }\end{array}$ & - & ++++ & ++ & +++ & $\begin{array}{l}\text { M. fortuitum biovar } \\
\text { peregrinum }\end{array}$ & $\begin{array}{l}\text { M. fortuitum biovar } \\
\text { peregrinum }\end{array}$ \\
\hline TMC 1545 & $\begin{array}{l}\text { M. fortuitum biovar } \\
\text { peregrinum }\end{array}$ & - & ++++ & +++ & +++ & $\begin{array}{l}\text { M. fortuitum biovar } \\
\text { peregrinum }\end{array}$ & $\begin{array}{l}\text { M. fortuitum biovar } \\
\text { peregrinum }\end{array}$ \\
\hline Broussard & $\begin{array}{l}\text { M. fortuitum biovar } \\
\text { peregrinum }\end{array}$ & - & ++++ & ++++ & +++ & $\begin{array}{l}\text { M. fortuitum biovar } \\
\text { peregrinum }\end{array}$ & $\begin{array}{l}\text { M. fortuitum biovar } \\
\text { peregrinum }\end{array}$ \\
\hline TMC 1547 & $\begin{array}{l}\text { M. fortuitum biovar } \\
\text { peregrinum }\end{array}$ & ++ & +++ & +++ & +++ & $\begin{array}{l}\text { Spontaneous } \\
\text { agglutination }\end{array}$ & $\begin{array}{l}\text { M. fortuitum biovar } \\
\text { peregrinum }\end{array}$ \\
\hline $1-73$ & Rapid grower & - & +++ & - & - & $\begin{array}{l}\text { M. fortuitum biovar } \\
\text { peregrinum }\end{array}$ & $\begin{array}{l}\text { M. fortuitum biovar } \\
\text { peregrinum }\end{array}$ \\
\hline $7-56$ & M. fortuitum & - & ++++ & ++ & ++ & $\begin{array}{l}\text { M. fortuitum biovar } \\
\text { peregrinum }\end{array}$ & $\begin{array}{l}\text { M. fortuitum biovar } \\
\text { peregrinum }\end{array}$ \\
\hline
\end{tabular}

a The unnamed group 3 biovar of $M$. fortuitum is differentiated from $M$. fortuitum biovar fortuitum and $M$. fortuitum biovar peregrinum by its ability to produce acid from inositol, mannitol, and sorbitol (4).

Chromatography of the lipids of the $M$. fortuitum biovars. TLC of the lipids from five isolates of $M$. fortuitum biovar peregrinum before (Fig. 5A) and after (Fig. 5B) alkali treatment revealed that the relevant and identifying spots again had the golden yellow to golden brown hue typical of the C-mycoside glycopeptidolipids. Again, we observed the characteristic accentuation and simplification of these components upon alkali treatment. Figure 6 shows the identifying lipids of a few isolates of $M$. chelonae subsp. chelonae and $M$. fortuitum biovar peregrinum after exposure to alkali in order to enhance the comparison. A less polar solvent was used to illustrate the various polarities of the glycolipids.

Figure 7 shows the results of TLC of the intact lipids from a selection of other $M$. fortuitum isolates, mostly biovar fortuitum. A number of patterns were observed. Pattern 1 occurs in lanes 2 through 4, 6 through 8,11 through 14,17 , and 19 and was characterized by a dark purple spot. Pattern 2 was more nondescript (lanes 5, 15, and 16); this pattern 


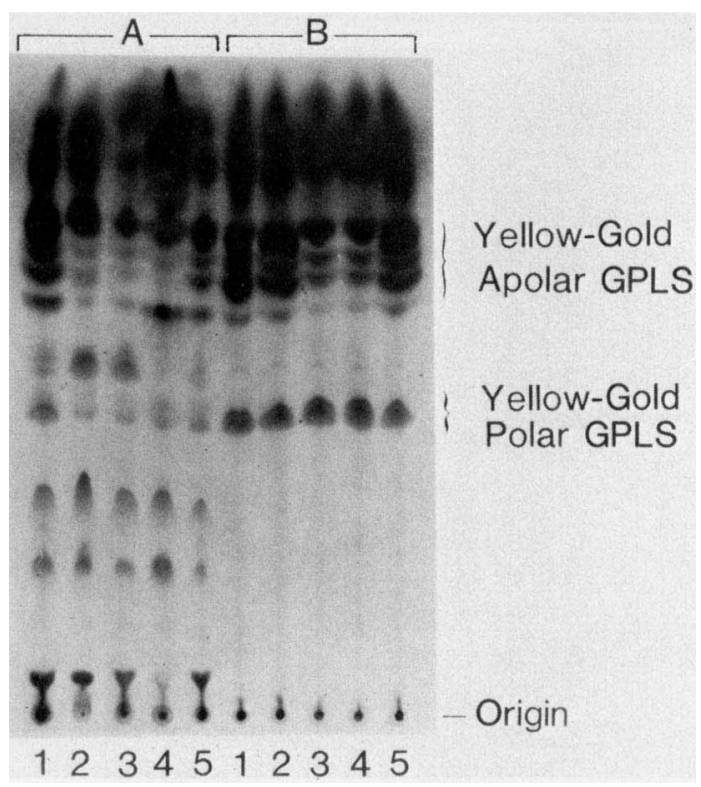

FIG. 5. TLC in $\mathrm{CHCl}_{3}-\mathrm{CH}_{3} \mathrm{OH}-\mathrm{H}_{2} \mathrm{O}(65: 25: 4)$ of the total lipids from five strains of $M$. fortuitum biovar peregrinum (see Table 2) (Starr-Glidden, TMC 1545, Broussard, TMC 1547, Rapid Grower [= 1-73]) and $M$. fortuitum 7-56. (A) Before alkaline treatment. (B) After alkaline treatment. GPLS, Glycopeptidolipids.

was identical to pattern 1 , except that the major purple spot was missing. Pattern 3 was characterized by a very distinct dark spot (lanes 1 and 9). A total of 29 isolates with a seroagglutination response indicative of $M$. fortuitum biovar fortuitum were examined; pattern 1 was observed in 15 , pattern 2 was observed in 12, and pattern 3 was observed in only 2 . Seemingly, only pattern 1 corresponds to the pattern described previously (13). Incidentally, the pattern in lanes 10 and 18 , with yellow to gold colors, was the pattern of the intact lipids from $M$. fortuitum biovar peregrinum. Shared characteristics of patterns 1 through 3 were the absence of any yellowish gold coloration and complete obliteration of the patterns with alkali. Figure 8, lanes 1 and 2, show pattern 1 before and after alkali treatment, and lanes 3 and 4 show pattern 3 before and after alkali treatment.

Absorption studies. Rabbit antibodies to $M$. chelonae subsp. chelonae were completely absorbed by strains of $M$. chelonae subsp. abscessus. Conversely, antibodies to $M$. chelonae subsp. abscessus were absorbed by strains of $M$. chelonae subsp. chelonae, and neither was absorbed by strains of $M$. fortuitum biovar peregrinum. Moreover, there was no change when $M$. fortuitum biovar fortuitum was used for absorption of $M$. fortuitum biovar peregrinum antisera (Table 3). We conclude on the basis of seroagglutination and antibody absorption that $M$. chelonae subsp. chelonae and $M$. chelonae subsp. abscessus are antigenically synonymous, whereas $M$. fortuitum biovar peregrinum may share some antigens, but is not homologous.

\section{DISCUSSION}

In this study we confirmed and extended the data of Jenkins et al. (13). Using TLC and the Schaefer seroagglutination protocol at a time that predated realization that the typing antigens and the specific lipids are synonymous, Jenkins et al. (13) observed that nonabsorbed $M$. chelonae subsp. abscessus antisera showed considerable cross-reac- tion with $M$. fortuitum biovar peregrinum but little crossreaction with $M$. fortuitum biovar fortuitum and that after absorption by $M$. fortuitum biovar peregrinum, the antisera still agglutinated $M$. chelonae subsp. abscessus. Similar absorptions were conducted in this work with $M$. chelonae subsp. chelonae with similar results, and our data indicated that the two $M$. chelonae subspecies show considerable homology, if not synonymy. Moreover, using the TLC approach, Jenkins et al. (13) observed that strains of $M$. chelonae subsp. abscessus contained a major lipid which yielded "a deep orange spot" in response to the orcinol spray. Somewhat similar descriptions had been given for the characteristic lipids of the MAIS complex (9), and we now realize that these are $\mathrm{C}$-mycoside glycopeptidolipids with a precise oligosaccharide determinant and are the actual typing antigens of the MAIS complex. At that time we believed that the glycopeptidolipid antigens were restricted to the MAIS complex. However, we have since determined that in addition to being present in $M$. chelonae and $M$. fortuitum biovar peregrinum, these antigens are also present in $M$. simiae serovars I and II and in $M$. malmoense (V. L. Barr, D. L. Yanagihara, A. Y. Tsang, J. K. McClatchy, and P. J. Brennan, unpublished data). The distinctive feature of the glycopeptidolipid antigen of $M$. chelonae is a 3,4-di- $O$ methylrhamnose substituent on the oligosaccharide moiety. Previously, we found this sugar linked only to the alaninol of the peptide entity $(6,8)$; in $M$. chelonae it apparently occurs at both the peptide and oligosaccharide termini. Also, the oligosaccharide, being a trisaccharide, is smaller than the tetrasaccharides found in the MAIS complex products; otherwise, the glycopeptidolipid molecules appear to be identical.

On the basis of a number of biochemical tests, an international consortium identified two subspecies of $M$. chelonae, $M$. chelonae subsp. chelonae and $M$. chelonae subsp. $a b$ scessus (14). In the present study we show that there is

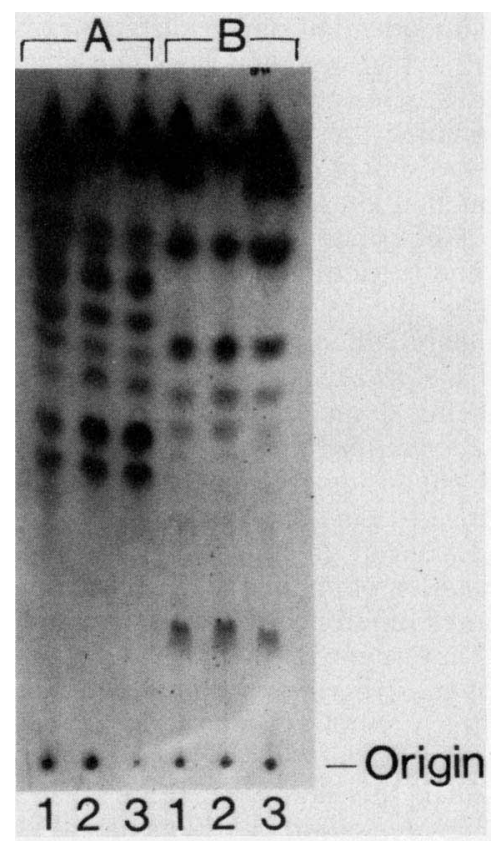

FIG. 6. TLC in a less polar solvent, $\mathrm{CHCl}_{3}-\mathrm{CH}_{3} \mathrm{OH}-\mathrm{H}_{2} \mathrm{O}$ (60:12:1), of the lipids from three of the authenticated isolates of $M$. chelonae subsp. chelonae (A) and $M$. fortuitum biovar peregrinum (B) after alkali treatment. 


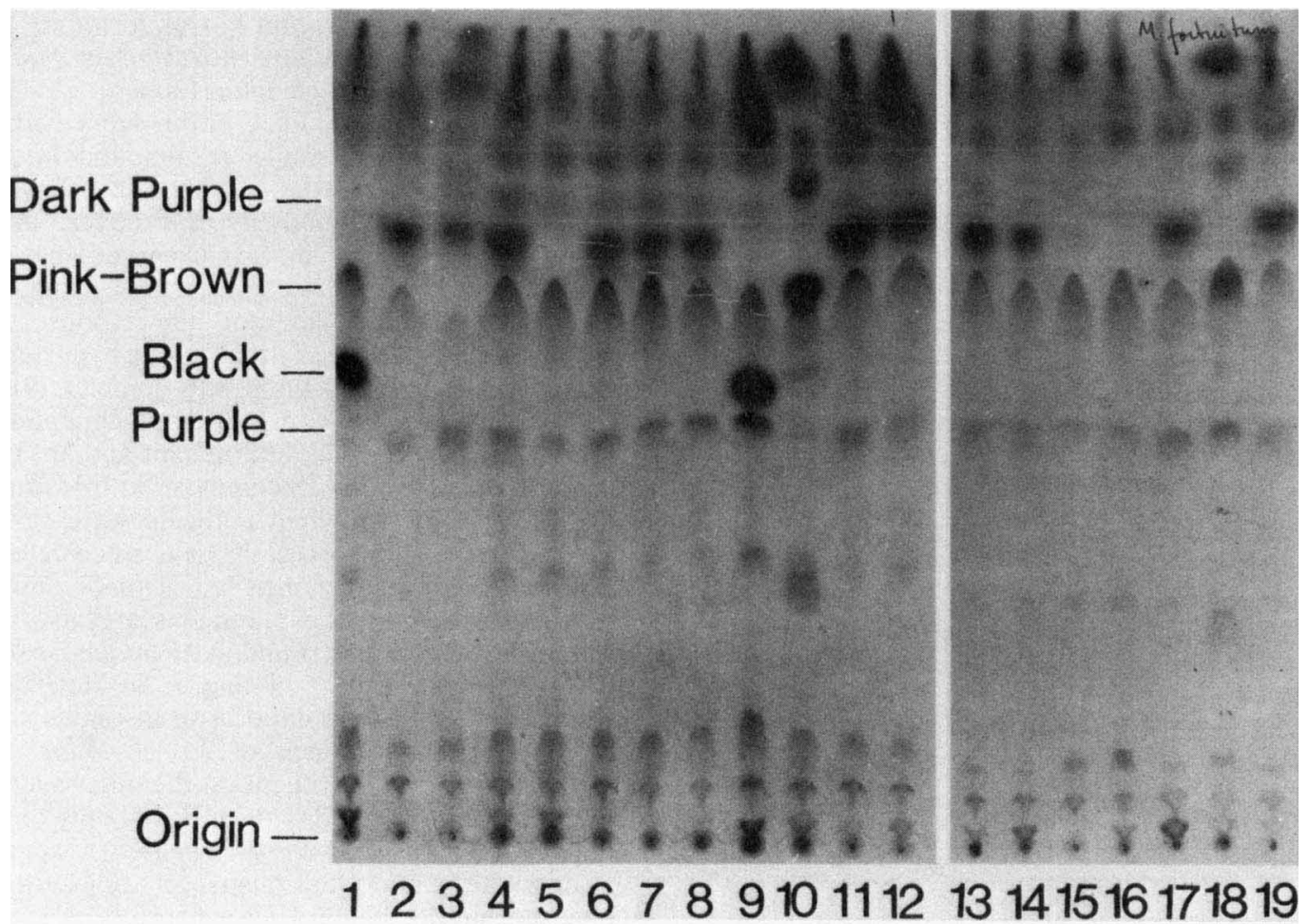

FIG. 7. TLC in $\mathrm{CHCl}_{3}-\mathrm{CH}_{3} \mathrm{OH}-\mathrm{H}_{2} \mathrm{O}(60: 16: 2)$ of the intact lipids from strains of $M$. fortuitum biovar fortuitum and $M$. fortuitum biovar peregrinum. Lane 1, strain 5-34; lane 2, strain 7-82; lane 3, strain 5-8; lane 4, strain 10-32; lane 5, strain 10-33; lane 6, strain 10-34; lane 7, strain 10-36; lane 8, strain 10-37; lane 9, strain 10-38; lane 10, strain 10-35; lane 11, strain 11-19; lane 12, strain 11-20; lane 13, strain 11-21; lane 14, strain 11-22; lane 15, strain 11-23; lane 16, strain 11-24; lane 17, strain 11-25; lane 18, strain 11-26; lane 19, strain TMC 1529.

essentially no difference between the two subspecies in what amounts to fundamental outer surface composition and antigenicity (2). Deoxyribonucleic acid-deoxyribonucleic acid homology studies performed by Baess (1) showed that the level of homology between $M$. chelonae subsp. chelonae and $M$. chelonae subsp. abscessus is $99 \%$. Baess supported the suggestion that these two strains belong to the same species. The electrophoretic patterns of the cytoplasmic proteins (10) and the antibiotic susceptibility characteristics (21) also support synonymy between the two subspecies.

The fundamental differences between $M$. fortuitum biovar fortuitum and $M$. fortuitum biovar peregrinum were revealed by simple chemical manipulations of the specific lipids. Those of $M$. fortuitum biovar peregrinum belong to the alkali-stable C-mycoside glycopeptidolipid class and are the serotyping antigens. On the other hand, $M$. fortuitum biovar fortuitum is devoid of glycopeptidolipids and is characterized by a population of distinct alkali-labile lipids. Jenkins et al. (13) also noted differences between the lipids of these two biovariants. They reported that the identifying lipid of $M$. fortuitum biovar peregrinum produced a "bright orange" response to the orcinol reagent, whereas extracts of $M$. fortuitum biovar fortuitum produced a pair of "double purple spots." In this study we found that strains which conform to the $M$. fortuitum designation by a number of parameters, including agglutination, exhibit a variety of lipid profiles, of which purple spots is just one; however, alkaline lability applies to all. Recently, we found that alkaline lability may indicate the presence of a class of novel anti-

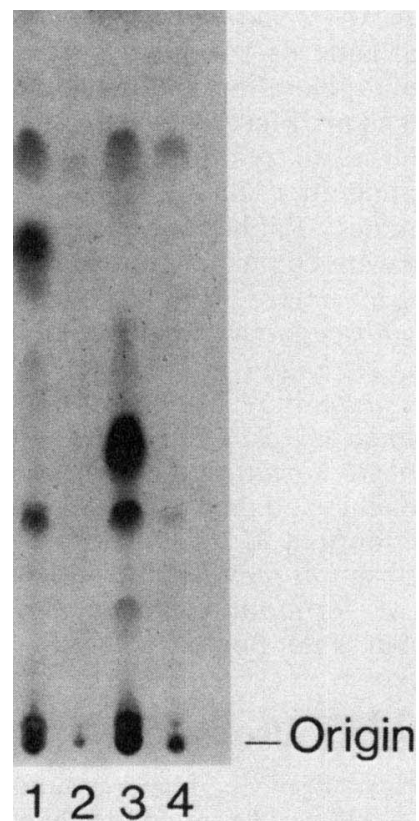

FIG. 8. TLC in $\mathrm{CHCl}_{3}-\mathrm{CH}_{3} \mathrm{OH}-\mathrm{H}_{2} \mathrm{O}(64: 10: 1)$ of lipids from $M$. fortuitum isolates representing patterns 1 and 3. Lane 1, Pattern 1; lane 2, pattern 1 after alkali treatment; lane 3, pattern 3; lane 4, pattern 3 after alkali treatment. 
TABLE 3. Agglutination reactions of sera prepared with strains of $M$. fortuitum biovar peregrinum, M. chelonae subsp. chelonae, and $M$. chelonae subsp. abscessus before and after absorption

\begin{tabular}{|c|c|c|c|}
\hline Strain used to prepare antiserum & Strain used to absorb antiserum & $\begin{array}{l}\text { Homologous } \\
\text { reaction before } \\
\text { absorption }\end{array}$ & $\begin{array}{l}\text { Homologous } \\
\text { reaction after } \\
\text { reaction }\end{array}$ \\
\hline M. fortuitum biovar fortuitum 6196 Smith & M. fortuitum biovar peregrinum New Mexico 680 & 0 & $\mathrm{ND}^{a}$ \\
\hline M. fortuitum biovar peregrinum New Mexico 680 & M. fortuitum biovar fortuitum 6196 Smith & 0 & ND \\
\hline M. fortuitum biovar peregrinum New Mexico 680 & M. chelonae subsp. abscessus TMC 1543 & $4+$ & 0 \\
\hline M. fortuitum biovar peregrinum New Mexico 680 & M. chelonae subsp. chelonae TMC 1544 & $4+$ & 0 \\
\hline M. chelonae subsp. chelonae TMC 1544 & M. fortuitum biovar fortuitum 6196 Smith & 0 & ND \\
\hline M. chelonae subsp. chelonae TMC 1544 & M. chelonae subsp. abscessus TMC 1543 & $4+$ & 0 \\
\hline M. chelonae subsp. abscessus TMC 1543 & M. chelonae subsp. chelonae TMC 1544 & $4+$ & 0 \\
\hline M. chelonae subsp. abscessus TMC 1543 & M. fortuitum biovar peregrinum New Mexico 680 & $1+$ & 0 \\
\hline
\end{tabular}

${ }^{a} \mathrm{ND}$, Not done, because there was no cross-reaction.

gens, the trehalose-containing lipooligosaccharides. The oligosaccharide substituent in the antigens from $M$. kansasii contain a trehalose moiety, xylose, 3-O-methylrhamnose, fucose, and a novel $N$-acyl amino sugar; in addition, the entire oligosaccharide is esterified by 2,4-dimethyltetradecanoyl groups (Hunter et al., in press). Analogous but species-specific lipooligosaccharide antigens characterize $M$. szulgai, Mycobacterium marinum, members of the $M y$ cobacterium gordonae complex, and presumably other nontuberculous mycobacteria (P. J. Brennan, S. W. Hunter, V. L. Barr, and D. M. Wynn, unpublished data). However, despite alkaline lability, we are not yet prepared to say that the characteristic lipids of $M$. fortuitum belong to the lipooligosaccharide class, because, unlike other workers, we have been unsuccessful in associating antigenicity with the lipids by using gel diffusion and ELISA technology.

The international consortium (14) concluded that $M$. fortuitum biovar fortuitum and $M$. fortuitum biovar peregrinum should be considered a "homologous assemblage." However, Baess (1) showed that on the basis of deoxyribonucleic acid-deoxyribonucleic acid homology, $M$. fortuitum biovar fortuitum is more related to $M$. fortuitum biovar peregrinum than to other species of mycobacteria; the levels of homology range from 47 to $57 \%$, and Baess concluded that $M$. fortuitum biovar fortuitum and $M$. fortuitum biovar peregrinum should be considered separate species. Our data support the proposal of Baess that $M$. fortuitum biovar fortuitum and $\boldsymbol{M}$. fortuitum biovar peregrinum should be differentiated, and we support the revival of "Mycobacterium peregrinum", as a species distinct from $M$. fortuitum.

\section{ACKNOWLEDGMENTS}

Most of the work was conducted at the National Jewish Hospital and Research Center/National Asthma Center and was supported by Public Health Service contract AI-02641 from the National Institute of Allergy and Infectious Diseases. The more detailed chemistry was conducted at Colorado State University and was supported by Public Health Service grant AI-18357 from the National Institute of Allergy and Infectious Diseases.

\section{LITERATURE CITED}

1. Baess, I. 1982. Deoxyribonucleic acid relatedness among species of rapidly growing mycobacteria. Acta Pathol. Microbiol. Immunol. Scand. Sect. B 90:371-375.

2. Barrow, W. W., B. P. Ullom, and P. J. Brennan. 1980. Peptidoglycolipid nature of the superficial cell wall sheath of smoothcolony-forming mycobacteria. J. Bacteriol. 144:814-822.

3. Bevelaqua, F. A., D. A. Kamelhar, J. Champion, and L. C. Christianson. 1981. Mycobacterium fortuitum-chelonei. Two patients with fatal pulmonary infections. N.Y. State J. Med. 81:1621-1624.
4. Bonicke, R. 1966. The occurrence of atypical mycobacterium in the environment of man and animal. Bull. Int. Union Tuberc. 37:361-368

5. Brennan, P. J., G. O. Aspinall, and J. E. Nam Shin. 1981. Structure of the specific oligosaccharides from the glycopeptidolipid antigens of serovars in the Mycobacterium aviumMycobacterium intracellulare-Mycobacterium scrofulaceum complex. J. Biol. Chem. 256:6817-6822.

6. Brennan, P. J., and M. B. Goren. 1979. Structural studies on the type-specific antigens and lipids of the Mycobacterium aviumMycobacterium intracellulare-Mycobacterium scrofulaceum serocomplex. J. Biol. Chem. 254:4205-4211.

7. Brennan, P. J., M. Heifets, and B. P. Ullom. 1982. Thin-layer chromatography of lipid antigens as a means of identifying nontuberculous mycobacteria. J. Clin. Microbiol. 41:447-455.

8. Brennan, P. J., J. Mayer, G. O. Aspinall, and J. E. Nam Shin. 1981. Structures of the glycopeptidolipid antigens from serovars in the Mycobacterium avium/Mycobacterium intracellulare/Mycobacterium scrofulaceum serocomplex. Eur. J. Biochem. 115:7-15.

9. Brennan, P. J., M. Souhrada, B. Ullom, J. K. McClatchy, and M. B. Goren. 1978. Identification of atypical mycobacteria by thin-layer chromatography of their surface antigens. J. Clin. Microbiol. 8:374-379.

10. Haas, H., J. Michael, and T. Sacks. 1974. Identification of Mycobacterium fortuitum, Mycobacterium abscessus, and Mycobacterium borstelense by polyacrylamide gel electrophoresis of their cell proteins. Int. J. Syst. Bacteriol. 24:366-369.

11. Hoffman, P. C., D. W. Fraser, F. Robicsek, P. R. O'Bar, and C. U. Mauney. 1981. Two outbreaks of postoperative wound infections due to organisms of the Mycobacterium fortuitum complex. J. Infect. Dis. 143:533-542.

12. Hunter, S. W., T. Fujiwara, and P. J. Brennan. 1982. Structure and antigenicity of the major specific glycolipid antigen of Mycobacterium leprae. J. Biol. Chem. 257:15072-15078.

13. Jenkins, P. A., J. Marks, and W. B. Schaefer. 1971. Lipid chromatography and seroagglutination in the classification of rapidly growing mycobacteria. Am. Rev. Respir. Dis. 103:179187.

14. Kubica, G. P., I. Baess, R. E. Gordon, P. A. Jenkins, J. R. G. Kwapinski, C. McDurmont, S. R. Pattyn, J. Saito, V. Silcox, J. L. Stanford, K. Takeya, and M. Tsukamura. 1972. A cooperative numerical analysis of rapidly growing mycobacteria. J. Gen. Microbiol. 73:55-70.

15. Pattyn, S. R., M. Magnusson, J. L. Stanford, and J. M. Grange. 1974. A study of $M$. fortuitum (ranae). J. Med. Microbiol. 7:6776.

16. Pattyn, S. R., A. Voller, D. E. Bidwell, and A. Bartlett. 1979. Practical aspects, p. 23-125. In The enzyme linked immunosorbent assay (ELISA), p. 23-125. Dynatech Laboratories, Inc., Alexandria, Va.

17. Runyon, E. H. 1959. Anonymous mycobacteria in pulmonary disease. Med. Clin. North Am. 43:273-290.

18. Schaefer, W. B. 1965 . Serologic identification and classification 
of the atypical mycobacteria by their agglutination. Am. Rev. Respir. Dis. 92(Suppl.):85-93.

19. Silcox, V. A., R. C. Good, and M. M. Floyd. 1981. Identification of clinically significant Mycobacterium fortuitum complex isolates. J. Clin. Microbiol. 14:686-691.

20. Stanford, J. L., S. R. Pattyn, F. Portaels, and W. J. Gunthrope. 1972. Studies on Mycobacterium chelonei. J. Med. Microbiol. 5:177-179.

21. Wallace, R. J., J. M. Swenson, V. A. Silcox, and R. C. Good.
1982. Disc diffusion testing with polymixin and amikacin for differentiation of Mycobacterium fortuitum and Mycobacterium chelonei. J. Clin. Microbiol. 16:1003-1006.

22. Winder, F. G., P. J. Brennan, and I. McDonnell. 1967. Effects of isoniazid on the composition of mycobacteria, with particular reference to soluble carbohydrates and related substances. Biochem. J. 104:385-393.

23. Wolinsky, E. 1979. Nontuberculous mycobacteria and associated diseases. Am. Rev. Respir. Dis. 119:107-159. 